NUKHBATUL 'ULUM : Jurnal Bidang Kajian Islam

Vol. 6, No. 1 (2020) : Hal. 77-104

Website: https://journal.stiba.ac.id

ISSN : 2685-7537 (online); 2338-5251 (Printed)

\title{
KRITIK TEOLOGI SALAFIYAH TERHADAP AHLI KALAM DALAM MEMAHAMI SIFAT-SIFAT ALLAH
}

\section{Criticism of Salafiyah Theology on the Various Interpretations of Al- Mutakallimun on the Attributes of Allah}

\author{
Muhammad Istiqamah \\ Sekolah Tingi Ilmu Islam dan Bahasa Arab (STIBA) Makassar \\ Email: muhammad.istiqamah@gmail.com
}

\begin{abstract}
Keywords :
Salafiyah, Al-Mutakallimun,

Attributes of Allah

ABSTRACT

This study aimed to examine the various interpretations of al-Mutakallimun on the attributes of Allah from the point of view of Salafiyah Theology, then the reasons behind the occurence of these interpretations as well as the Salafiyah Theological criticism against that understanding. The method used in this study was library research referring to classical and modern literature. The research conducted in this study shows that there are several Salafiyah Theological criticisms against these various interpretations of al-Mutakallimun on the attributes of Allah. Among other things, there is a fallacious perception that if one were to define the attributes of Allah in accordance with their meanings, one would fall on tasybih on those attibutes or on the consequences of those attribute. Therefore, some al-Mutakallimun find solutions in Tafwidh and Ta'wil, and claim that the two are the way to purify and glorify Allah. Besides, there is a mistake in understanding Arabic expressions according to the context.

Kata kunci : ABSTRAK

Salafiyah, Ahli Kalam, Sifat-sifat Allah

Penelitian ini bertujuan mengkaji ragam interpretasi Ahli Kalam terhadap sifatsifat Allah dari sudut pandang Teologi Salafiyah, kemudian sebab atas munculnya interpretasi tersebut serta kritik Teologi Salafiyah atas pemahaman tersebut. Metode yang digunakan dalam penelitian ini adalah penelitian pustaka. Dengan merujuk pada literatur klasik dan modern. Kajian yang dilakukan dalam penelitian ini menunjukkan bahwa terdapat beberapa kritik Teologi Salafiyah atas ragam interpretasi Ahli Kalam terhadap sifat-sifat Allah. Di antaranya, adanya persepsi yang keliru bahwa jika menetapkan sifat-sifat Allah sesuai dengan maknanya akan terjatuh pada tasybih pada sifat tersebut atau pada konsekuensi dari sifat tersebut. Sehingga sebagian Ahli Kalam mendapatkan solusi pada Tafwidh dan Ta'wil, dan diklaim itulah cara untuk mensucikan dan mengagungkan Allah. Kemudian, adanya kekeliruan dalam memahami ungkapan bahasa Arab sesuai konteksnya.
\end{abstract}

Riwayat artikel: Diterima: 13 Maret 2020; Direvisi: 9 Mei 2020; Disetujui: 9 Mei 2020; Tersedia online: 12 Juni 2020.

How to cite : Istiqamah, M. (2020). Kritik Teologi Salafiyah Terhadap Ahli Kalam dalam Memahami Sifat-sifat Allah. NUKHBATUL 'ULUM: Jurnal Bidang Kajian Islam, 6(1), 77-104. https://doi.org/10.36701/nukhbah.v6i1.101 


\section{PENDAHULUAN}

Mengenal Allah (ma'rifatullah) sebagaimana yang diinginkan Allah dan RasulNya merupakan ilmu paling agung dan paling utama. Bahkan ilmu ini didahulukan atas yang lainnya. Karena ini menjadi dasar dan asas keberislaman seseorang yang bisa mengantarkannya pada keselamatan dan kebahagiaan hakiki.

Dalam upaya mengenal Allah melalui nama-nama dan sifat-sifat-Nya, Allah Subhanahu wa ta'ala menetapkan satu kaidah yang bisa dikatakan menjadi qanun dan batasan. Yakni firman Allah,

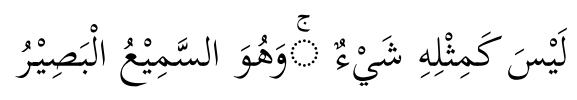

(artinya), "Dia tidaklah serupa dengan sesuatu apapun, dan Dia adalah maha mendengar lagi maha mengetahui."

Berangkat dari ayat ini, semua Ahlul Qiblah ${ }^{2}$ berusaha mensucikan Allah (tanzih) dari segala macam penyerupaan, kekurangan dan segala hal yang dipandang dapat mencederai kemahabesaran dan keagungan-Nya.

Banyak ungkapan dalam Al-Qur'an yang menunjukkan bahwa itu merupakan sifat-sifat Allah. Seperti ungkapan, "Allah menyayangi," "Allah mencintai," "Allah marah," "Allah murka," "tangan Allah di atas tangan mereka,"dan selainnya.

Ahlul Qiblah dengan ragam kelompoknya memiliki interpretasi yang berbedabeda mengenai sifat-sifat Allah tersebut.

Para mutakallimin dari kalangan Jahmiyah ${ }^{3}$, Mu'tazilah ${ }^{4}$, Asy'ariyah ${ }^{5}$, Maturidiyah ${ }^{6}$ menjadi kelompok yang paling sering tampil dalam panggung perdebatan mengenai sifat-sifat Allah dan saling melemparkan kritik antara satu kelompok dengan yang lainnya.

Kelompok Salafiyah termasuk dalam pusaran Ahlul Qiblah yang memberikan kritiknya kepada kelompok-kelompok tersebut.

Salah satu pemahaman terhadap sifat-sifat Allah dalam teologi Salafiyah meyakini bahwa sifat-sifat Allah yang disebutkan di dalam Al-Qur'an maupun dalam hadis haruslah disertai dengan pemahaman terhadap maknanya sedangkan pemahaman terhadap hakikat sebenarnya dari wujud sifat tersebut diserahkan kepada Allah swt.

\footnotetext{
${ }^{1}$ Al-Qur'an, Asy-Syura/42: 11.

${ }^{2}$ Semua umat Islam yang kiblatnya ke Ka'bah di Mekkah.

${ }^{3}$ Pengikut Ja'ad bin Dirham (w. $118 \mathrm{H}$ ) dan Jahm bin Shafwan (w. $128 \mathrm{H}$ ).

${ }^{4}$ Pengikut Washil bin Atha (w. $131 \mathrm{H}$ ) dan Amr bin Ubaid (w. $144 \mathrm{H}$ ).

${ }^{5}$ Pengikut Abu Al-Hasan Al-Asy'ari (w. $324 \mathrm{H}$ ).

${ }^{6}$ Pengikut Abu Manshur Al-Maturidi (w. $333 \mathrm{H}$ ).
} 
Namun pemahaman seperti ini dianggap oleh sebagian kelompok sebagai tasybih (bentuk penyerupaan Allah terhadap makhluk-Nya). Bahkan menilai bahwa ungkapan-ungkapan semacam, "Terserah yang di atas," "Tuhan tertawa," dan lain sebagainya sudah dianggap sebagai bentuk kekafiran meskipun yang mengucapkannya tidak bertujuan keluar dari agama Islam. ${ }^{7}$

Bahkan menarasikan sifat-sifat Allah dengan pemahaman terhadap maknanya dianggap sebagai faham tajsim $^{8}$. .

Para ulama kelompok Salafiyah tentunya memiliki jawaban atas beberapa kritikan tersebut, bahkan bertolak dari situ mereka melakukan kritik balik.

Pemahaman Ahli Kalam terhadap sifat-sifat Allah dengan ragam firqahnya dikritik oleh para ulama kelompok Salafiyah. Seperti bantahan Imam Ahmad bin Hambal kepada Jahmiyah dalam kitabnya, Ar-Radd 'Ala Al-Jahmiyyah wa AzZanadiqah, Imam Bukhari dengan kitabnya, Khalqu Af'al Al-'Ibad, hingga Syaikhul Islam Ibnu Taimiyah dalam banyak kitabnya seperti, Bayan Talbis AlJahmiyah, Dar'u Ta'arudh Al-'Aql li An-Naql, Minhaj As-Sunnah AnNabawiyah, Risalah Al-Hamawiyah dan Risalah At-Tadmuriyah.

Juga oleh para ulama kontemporer seperti Syaikh Muhammad bin Shalih Al'Utsaimin dalam Al-Qawa'id Al-Mutsla-nya. Syaikh Abdullah bin Muhammad Al-Ghunaiman dalam Syarah Kitab Tauhid Min Shahih Al-Bukhari dan Syaikh Abdul Aziz Ath-Tharifi dalam dua kitab syarahnya untuk matan aqidah, AlKhurrasaniyah dan Al-Maghribiyah.

Tentunya para ulama tersebut membantah Ahli Kalam karena diyakini ada kekeliruan dalam pemahaman mereka terhadap sifat-sifat dan perbuatan Allah.

Kekeliruan ini dalam Al-Qur'an disebut sebagai ilhad,

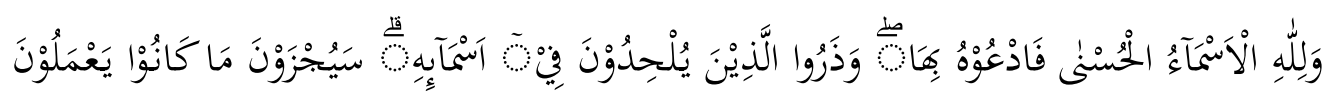

(artinya), "Dan Allah memiliki nama-nama yang indah maka berdoalah dengannya, dan biarkanlah orang-orang yang mengingkari (melakukan ilhad) dalam nama-nama-Nya, mereka akan dibalas atas apa yang mereka lakukan."10

Ilhad secara istilah adalah berpaling dari sesuatu yang wajib ada padanya. ${ }^{11}$ Olehnya itu, semua bentuk penyimpangan dalam memahami nama-nama dan

${ }^{7}$ Kholilurrohman, Meluruskan Distorsi Dalam Ilmu Kalam (Tangerang: Nurul Hikmah Press, 2018).

${ }^{8}$ Faham yang menyatakan bahwa Allah memiliki anggota badan (jism).

${ }^{9}$ Abdurrahman Khalifah, Al-Musyabbihah wa Al-Mujassimah (Cairo: Al-Maktabah Al-Takhassusiyah li AlRadd Ala Al-Wahhabiyah, $1420 \mathrm{H})$.

${ }^{10} \mathrm{Al}-$ Qur'an, Al-A'raf/7: 180.

${ }^{11}$ Muhammad bin Shalih Al-Utsaimin, Al-Qawaid Al-Mutsla fi Shifatillahi Ta'ala wa Asmaihi Al-Husna (Riyadh: Madar Al-Watan, 1435), h. 25. 


\section{NUKHBATUL 'ULUM : Jurnal Bidang Kajian Islam}

Vol. 6, No. 1 (2020) : Hal. 77-104

Website: https://journal.stiba.ac.id

ISSN : 2685-7537 (online); 2338-5251 (Printed)

sifat-sifat Allah seperti ta'thil, ${ }^{12}$ tamtsil, $^{13}$ takyif, $^{14}$ tafwidh, $^{15}$ tahrif, $^{16}$ dan ta'wil' ${ }^{17}$ masuk dalam makna ilhad. ${ }^{18}$

Berdasarkan hal ini, permasalahan penelitian yang ingin dijawab adalah bagaimana kelompok Salafiyah menilai bentuk dan ragam pemahaman Ahli Kalam dalam memahami sifat-sifat Allah? Apa alasan dan sebab pemahaman Ahli Kalam tersebut? Bagaimana kritik kelompok Salafiyah terhadap pemikirian Ahli Kalam dalam memahami sifat-sifat Allah?

Penelitian ini dilakukan untuk menjawab permasalahan tersebut dengan tujuan untuk mengkaji ragam bentuk penafsiran Ahli Kalam terhadap sifat-sifat Allah, hal-hal yang menyebabkan Ahli Kalam memilih penafsiran tersebut serta kritik dan tanggapan kelompok Salafiyah atas pemikiran Ahli Kalam dalam memahami sifat-sifat Allah.

Ada beberapa penelitian terdahulu yang juga membahas pemahaman Ahli Kalam terhadap sifat-sifat dan perbuatan Allah, yaitu:

Hadi Rafitra meneliti aliran Asy'ariyah secara khusus dengan mengkaji secara historis dan pengaruhnya terhadap dunia Islam. Kajian ini menganalisa kemunculan Asy'ariyah sebagai reaksi terhadap faham Muktazilah, tokoh-tokoh dalam Asy'ariyah, pengaruhnya dan penyebarannya di masyarakat, serta ciri-ciri penganut aliran Asy'ariyah. Di antara ciri yang ditonjolkan dalam penelitian ini adalah pendirian Abu Al-Hasan Al-'Asy’ari terhadap Kalamullah. Dimana menurutnya perlu dibedakan antara Kalamullah yang berdiri dengan Dzat-Nya yang berarti Qadim dengan wujud Al-Qur' an yang ada di antara kita. ${ }^{19}$

Bahrul Ulum melakukan kajian terhadap dinamika kemunculan dan perkembangan ilmu kalam dalam lingkup sunni. Tiga mazhab pemikiran Sunni masuk dalam kajian ini; Asy'ariyah, Tahawi dan Maturidi. Selain itu, penelitian ini juga membandingkan metodoligi mazhab teologi Sunni dengan Muktazilah dalam beberapa terma kajian dalam lingkup sifat dan perbuatan Allah. Kemudian, penelitian ini juga mengkaji kritik Ibnu Taimiyah terhadap Kalam Sunni. Konsep Al-Kasb dalam faham Asy'ariyah menjadi fokus kritik. Menurut

\footnotetext{
${ }^{12}$ Mengingkari apa yang wajib bagi Allah dalam Asma' dan sifatNya, atau mengingkari sebagiannya. Muhammad bin Ibrahim Al-Hamd, Rasail fil 'Aqidah (Riyadh: Dar Ibnul Juazi, 1439), h. 210.

${ }^{13}$ Meyakini bahwa sifat-sifat Allah sama dengan sifat makhluk. Al-Hamd, Rasail fil 'Aqidah, h. 210.

${ }^{14}$ Menggambarkan sifat Allah seperti mengatakan tangan Allah seperti ini dan itu, atau bertanya-tanya tentang sifat Allah, Al-Hamd, Rasail fil 'Aqidah, h. 211.

${ }^{15}$ Memastikan bahwa makna teks sifat-sifat Allah tidak diketahui kecuali Allah sendiri. Al-Hamd, Rasail fil 'Aqidah, h. 211.

${ }^{16}$ Merubah teks atau merubah makna. Al-Hamd, Rasail fil 'Aqidah, h. 211.

${ }^{17}$ Mengalihkan makna lafaz dari zahirnya kepada makna yang menyelisihi zahirnya. Al-Hamd, Rasail fil 'Aqidah, h. 212.

${ }^{18}$ Al-Hamd, Rasail fil 'Aqidah, h. 209.

${ }^{19}$ Hasibuan, Hadi Rafitra, “Aliran Asy’ariyah, Kajian Historis dan Pengaruh Aliran Kalam Asy'ariyah”, Jurnal Al-Hadi, 2, no. 2 (2017): h. 433-441.
} 
Ibnu Taimiyah, teori Al-Kasb ini bukannya menengahi antara Jabariyah dan Qadariyah, melainkan lebih mendekati kaum Jabariyah. ${ }^{20}$

Ilhamuddin dan Muhammad Lathief meneliti teologi Islam dengan berbagai dinamika dan tema-tema pokoknya serta perbandingan teologi Islam klasik dan modern. Kajian ini lebih pada komparasi berbagai mazhab dalam teologi Islam dengan ragam tema yang disebutkan. Yaitu, Al-Iman wa Al-Kufr, Al-Wa'd wa Al-Wa'id, Af'al Al-'Ibad, Kalam Allah dan Ru'yat Allah. ${ }^{21}$

Adapun penelitian ini berbeda dengan penelitian-penelitian sebelumnya karena penelitian ini bukan hanya komparasi pemahaman dan interpretasi Ahli Kalam terhadap sifat dan perbuatan Allah. Tapi juga membahas aspek yang lebih dalam yaitu meneliti dari sudut pandang Teologi Salafiyah mengenai sebab utama atas munculnya beragam pemahaman dan interpretasi Ahli Kalam terhadap sifat dan perbuatan Allah serta kritik Teologi Salafiyah atas pemahaman tersebut.

\section{METODE}

Metode yang digunakan dalam penelitian ini adalah metode pendekatan kualitatif-deskriptif dengan teknik content analysis (analisis isi) dan library research (riset kepustakaan). Teknik content analysis merupakan metode penelitian yang digunakan untuk mengetahui simpulan dari sebuah teks. Atau dengan kata lain, analisis isi merupakan metode penelitian yang ingin mengungkap gagasan penulis yang termanifestasi maupun yang laten. Sementara riset kepustakaan (library research) pada penelitian ini menggunakan jenis dan sumber data sekunder yang diperoleh dari hasil penelitian, artikel dan buku-buku referensi yang membahas topik yang berkaitan dengan tema penelitian. ${ }^{22}$

\section{PEMBAHASAN}

Para ulama kelompok Salafiyah menyebutkan bahwa dalam memahami dan mengimani sifat-sifat Allah setidaknya ada tiga hal yang mesti dilakukan. ${ }^{23}$

Yang pertama adalah Itsbat, yakni menetapkan apa yang Allah tetapkan untuk diri-Nya dalam kitab-Nya atau melalui lisan Rasul-Nya dan juga menetapkan maknanya serta hakikatnya yang layak untuk Allah dengan segala keagunganNya tanpa tahrif, ta'thil, takyif dan tamtsil.

Kedua $A n-N a f y u$, meniadakan atau menafikan. Yakni menafikan apa yang Allah nafikan untuk diri-Nya dalam kitab-Nya atau yang dinafikan oleh Rasul-Nya dengan meyakini kesempurnaan kebalikan dari sifat yang dinafikan.

\footnotetext{
${ }^{20}$ Ulum, Bahrul, "Dinamika Ilmu Kalam Sunni”, Jurnal Pemikiran dan Pendidikan Islam El-Banat, 6, no. 2 (2016): h. 143-154.

${ }^{21}$ Ilhamuddin., \& Ilhamy Nasution, Muhammad Lathief. Teologi Islam, Warisan Pemikir Muslim Klasik. (Medan: Perdana Publishing, 2017).

${ }^{22}$ Iskandar, A., Aqbar, K, "Reposisi Praktik Ekonomi Islam: Studi Kritis Praktik Ekonomi Islam di Indonesia", Nukhbatul Ulum: Jurnal Bidang Kajian Islam, 5, no. 1 (2019): h. 42-43.

${ }^{23}$ Al-Hamd, Rasail fil 'Aqidah, h. 181.
} 
Ketiga Tawaqquf, atau berhenti, tidak menetapkan dan tidak menafikan karena tidak disebutkan dalam teks-teks syariat seperti yang diperdebatkan oleh para Ahli Kalam berupa kata al-jism (anggota badan), al-jihhah (arah), al-makan (tempat) dan yang lainnya.

Para ulama kelompok Salafiyah menilai mazhab para Mutakallimin bahwa hampir semuanya, kalau tidak dikatakan seluruhnya terjatuh dalam poin yang pertama. Yakni tidak menetapkan sifat-sifat tersebut dengan makna dan hakikatnya yang layak untuk Allah.

Tingkatannya pun berbeda-beda, sebagian kelompok Ahli Kalam menolak seluruh nama dan sifat Allah seperti Jahmiyah ${ }^{24}$, sebagiannya menetapkan namanama Allah (Asmaul Husna) namun mengingkari sifat-sifat-Nya seperti Mu'tazilah $^{25}$, dan sebagian yang lain punya dua cara, pertama, menetapkan sifatsifat Allah dengan mengosongkan maknanya dan mengatakan hanya Allah yang tahu (tafwidh) atau kedua, dengan menetapkan sifat-sifat tersebut namun dengan makna lain (ta'wil), kedua cara ini yakni tafwidh dan ta'wil ditempuh oleh Asy'ariyah dan Maturidiyah. ${ }^{26}$

Dari penyikapan yang berbeda-beda ini para ulama kelompok Salafiyah menilai bahwa ragam interpretasi para Ahli Kalam tersebut berangkat dari dasar pemikiran yang sama. Setidaknya tertuang dalam empat poin berikut:

\section{Tawahhum Tasybih}

Hampir semua penyikapan atau penafsiran Ahli Kalam terhadap sifat-sifat Allah berasal dari Tawahhum Tasybih. Yakni prasangka bahwa jika menetapkan sifat Allah dengan maknanya akan terjatuh pada penyerupaan Allah dengan makhlukNya (tasybih dan tamtsil). Ini menjadi poin utama kekhawatiran para Ahli Kalam. ${ }^{27}$

Agar lebih jelas, kita paparkan dalam contoh berikut.

Sifat Al-Kalam merupakan salah satu sifat Allah yang diperdebatkan oleh Ahli Kalam. Di dalam Al-Qur'an Allah berfirman,

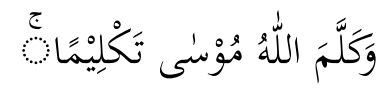

(artinya), "Dan Allah benar-benar berbicara dengan Musa.", 28

\footnotetext{
${ }^{24}$ Abdul Qadir 'Atha' Shufi, Muqaddimat fi Al-Firaq wa Al-Iftiraq (Madinah: Dar Imam Muslim, 1439 H), h. 103.

${ }^{25}$ Ibnu Taimiyah, Minhaj Al-Sunnah Al-Nabawiyah, Vol. 2 (Riyadh: Univ. Islam Imam Muhammad bin Su'ud, 1406 H), h. 604.

${ }^{26}$ Thaha Khalid Al-Sayyid Ali Al-Samarra'i, Masa'il Al-Khilaf Baina Al-'Asy'ariyyah wa Al-Maturidiyyah (Beirut: Dar Al-Kutub Al-'Ilmiyyah, n.d.) h. 85.

${ }^{27}$ Abdul Aziz Al-Tharifi, Al-Maghribiyah fi Syarh Al- 'Aqidah Al-Qairawaniyyah (Riyadh: Maktabah Dar AlMinhaj, 1438 H), h. 93.

${ }^{28} \mathrm{Al}$-Qur'an, An-Nisa'/4: 164.
} 
(artinya), "Dan Rabbnya berbicara padanya (Nabi Musa)."29

Ahli Kalam menganggap jika menetapkan bahwa Allah berbicara otomatis menyerupakan Allah dengan makhluk-Nya. Karena yang difahami bahwa semua yang berbicara pasti menggunakan mulut, butuh terhadap nafas, rongga perut, tenggorokan dan yang lainnya. ${ }^{30}$ Dan ini tidak mungkin bagi Allah, karena ini menyerupai makhluk. Sedangkan Allah tidak mungkin sama dengan makhlukNya. Sehingga Ahli Kalam menafikan bahwa Allah berbicara dengan Nabi Musa alaihis salam.

Lalu apa makna kalam (berbicara) dalam ayat di atas menurut interpretasi mereka?

Menurut Jahmiyah dan Muktazilah ${ }^{31}$, kalam disini adalah makhluk yang Allah ciptakan dan makhluk itulah yang berbicara.

Mengenai Jahmiyah, Imam Ahmad bin Hambal rahimahullah mengatakan, "Mereka mengatakan bahwa Allah tidak akan berbicara dan tidak berbicara, Dia hanyalah menciptakan sesuatu dan sesuatu itu yang berbicara mewakili Allah, lalu menciptakan suara dan memperdengarkan suara tersebut." ${ }^{32}$

Adapun Muktazilah, salah satu pembesar mereka, Al-Qadhi Abdul Jabbar mengatakan, "Adapun mazhab kami, yaitu bahwa Al-Qur'an adalah perkataan Allah dan wahyu-Nya dan ia adalah makhluk muhdats (sesuatu yang baru)." ${ }^{\text {"33 }}$

Mereka meyakini bahwa semua yang disebut sebagai Kalamullah adalah makhluk yang Allah ciptakan dan berbicara atas nama Allah. Olehnya itu, lahirlah keyakinan berikutnya bahwa Al-Qur'an adalah makhluk. Karena makhluk yang berbicara atas nama Allah.

Sedangkan Kullabiyah ${ }^{34}$ dan Asy'ariyah mengatakan bahwa Allah berbicara dalam diri-Nya sendiri dan tidak memperdengarkannya kepada siapapun, mereka menyebutnya dengan Al-Kalam Al-Nafsi. ${ }^{35}$

Abu Hamid Al-Ghazali mengatakan, "Kami tidak menetapkan pada Allah Ta'ala kecuali Kalam Al-Nafs. Dan tidak ada jalan untuk mengingkarinya terjadi pada

\footnotetext{
${ }^{29}$ Al-Qur'an, Al-A'raf/7: 143.

${ }^{30}$ Al-Tharifi, Al-Maghribiyah Fi Syarh Al-'Aqidah, h. 145.

${ }^{31}$ Jabir Idris Ali Amir, Manhaj Al-Salaf wa Al-Mutakallmin fi Muwafaqati Al-'Aql li Al-Naql wa Atsaru AlManhajaini fi Al-'Aqidah, Vol. 2 (Riyadh: Maktabah Adhwa' As-Salaf, 1419 H), h. 804.

${ }^{32}$ Ahmad bin Hambal, Al-Radd 'Ala Al-Jahmiyah (Riyadh: Dar Al-Tsabat, 1424 H), h. 135-136.

${ }^{33}$ Al-Qadhi Abdul Jabbar, Syarh Ushul Al-Khamsah (Cairo: Maktabah Wahbah, 1416 H), h. 528

${ }^{34}$ Pengikut Abdullah bin Said bin Kullab Al-Qattan (w. setelah tahun $240 \mathrm{H}$ ) yang keyakinannya banyak diikuti oleh Abu Al-Hasan Al-'Asy'ari dan Asy'ariyah.

${ }^{35}$ Karim Imam, Al-'Asya'irah Su'al wa Jawab (Al-Manshurah-Mesir: Dar Al-Lu'lu'ah, n.d.) h. 101.
} 
manusia yang melebihi kuasa dan suara. Orang berkata, semalam saya utarakan dalam diriku sebuah perkataan." 36

Sebenarnya Asy'ariyah juga meyakini seperti yang diyakini oleh Muktazilah bahwa Al-Qur'an adalah makhluk.

Al-Iji mengatakan, "Ketahuilah bahwa apa yang dikatakan Muktazilah yaitu terciptanya suara dan huruf dan ia adalah muhdats maka kami pun mengatakan seperti itu. Tidak ada perselisihan antara kami dengan mereka. Adapun pendapat kami tentang Kalam Al-Nafs, ini mereka ingkari."37

Letak kesamaan dan perbedaan keyakinin Asy'ariyah dengan Muktazilah kemudian dijelaskan lebih lanjut oleh Muhammad Sa'id Ramadhan Al-Buthi, "Adapun jumhur kaum muslimin, Ahlussunnah wal Jamaah mereka mengatakan kami tidak mengingkari yang dikatakan oleh Muktazilah, kita pun mengatakan demikian dan kita sebut dengan Kalam Lafzhi. Kita semua sepakat bahwa ia adalah sesuatu yang muhdats dan tidak berbarengan dengan Dzat Allah, karena kemuhdatsannya tersebut. Namun kita menetapkan sesuatu di balik itu, yakni sifat yang terjadi dalam diri yang diungkapkan dengan lafaz. Dan disinilah Muktazilah berbeda dengan jumhur, dimana mereka tidak menyandarkan pada Allah sifat qadim dengan pengertian Kalam Al-Nafs." 38

Ragam interpretasi ini bersumber dari kekhawatiran jika menetapkan Allah berbicara seperti ketika berbicara dengan Nabi Musa alahis salam akan terjatuh pada penyerupaan pada dua hal.

Yang pertama bahwa huruf dan suara muncul secara berurutan. Sehingga hal itu adalah sesuatu yang baru. Dan Allah disucikan dari hawadits (munculnya sesuatu yang baru terjadi pada Allah). Dan seperti ini juga yang difahami ketika menafikan sifat Istiwa', Nuzul, Al-Qabdh dan yang lainnya.

Yang kedua bahwa semua yang berbicara itu pasti menggunakan mulut, rongga perut, tenggorokan dan yang lainnya.

Padahal, kata Syaikh Abdul Aziz Al-Tharifi, jika demikian pemahamannya terhadap munculnya sesuatu secara berurutan mestinya mereka juga akan menolak sifat Al-Sam'u dan Al-Bashar. Seperti ketika seoarang hamba berdoa, Ya Rabb. Yang didengar terlebih dahulu adalah huruf ya', kemudian ra' dan seterusnya.

Ini terjadi pada makhluk, namun disangka juga terjadi pada Allah ketika menetapkan sifat Al-Kalam. Sedangkan Allah berbuat sekehendak-Nya, bagaimanapun Allah inginkan dan kapan saja. Termasuk kalam-Nya.

\footnotetext{
${ }^{36}$ Abu Hamid Al-Ghazali, Al-Iqtishad fi Al-I'tiqad (Beirut: Dar Al-Kutub Al-'Ilmiyyah, 1403 H), h. 75

${ }^{37}$ Abdurrahman bin Ahmad Al-Iji, Al-Mawaqif fi 'Ilm Al-Kalam (Beirut: 'Alam Al-Kutub, t.t.), h. 294 h. 125-126.

${ }^{38}$ Muhammad Sa'id Ramadhan Al-Buthi, Kubra Al-Yaqiniyyat Al-Kauniyyah (Damaskus: Dar Al-Fikr, 1982),
} 
Kemudian untuk poin yang kedua kalau kita lihat di antara makhluk-Nya saja ada yang berbicara dengan tidak menggunakan mulut, tidak membutuhkan nafas, rongga perut dan tenggorokan. Seperti Allah sebutkan dalam firman-Nya tentang bicaranya langit dan bumi,

(artinya), "Mereka berdua (langit dan bumi) mengatakan kami datang dalam keadaan taat." 39 ,

Juga mengenai kulit dan anggota tubuh lain selain mulut yang Allah jadikan mereka bisa berbicara di hari kiamat,

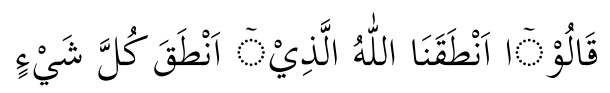

(artinya), "Mereka berkata, kami dibuat berbicara oleh Allah yang membuat berbicara segala sesuatu." 40

Kedua ayat ini berbicara mengenai makhluk-Nya, yang satu benda mati (langit dan bumi), sedang yang satunya lagi anggota tubuh. Dan semuanya berbicara dengan tidak memakai mulut, tidak membutuhkan nafas, dan tenggorokan.

Dan bagi Allah permisalan yang lebih tinggi lagi (Qiyas Al-Aula). Jika pada makhluk-Nya saja hal ini bisa terjadi, dan bukan sesuatu yang mustahil. Tentunya lebih mungkin lagi bagi Allah Swt.

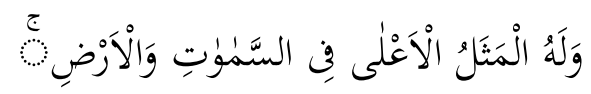

(artinya), "Dan Dia memiliki permisalan yang lebih tinggi di langit dan bumi.",41

Sangat mungkin dan tidak ada yang mustahil bagi Allah untuk hanya sekedar berbicara, kapanpun dan bagaimanapun Allah inginkan dengan hakikat yang layak bagi kemuliaan dan keagungan-Nya.

Dan ini Allah sebutkan dalam banyak dalil. Allah berbicara dengan nabi Musa, ${ }^{42}$ Allah berbicara dengan makhluk-Nya di hari kiamat kelak ketika dihisab satu persatu, ${ }^{43}$ Allah berbicara dengan neraka, ${ }^{44}$ Allah berbicara dengan malaikat Jibril, ${ }^{45}$ Allah berbicara dan menjawab orang-orang yang salat ketika mengucapkan Alhamdulillahi Rabbil 'Alamin dengan firman-Nya, (artinya), "Hambaku memujiku," 46 dan dalil-dalil lain yang menyebutkan bahwa Allah

\footnotetext{
${ }^{39} \mathrm{Al}-\mathrm{Qur}$ 'an, Fushilat/41: 11.

${ }^{40} \mathrm{Al}-\mathrm{Qur}$ 'an, Fushshilat/41: 21

${ }^{41} \mathrm{Al}-\mathrm{Qur}$ 'an, Ar-Rum/30: 27.

${ }^{42} \mathrm{Al}$-Qur'an, An-Nisa'/4: 164.

${ }^{43}$ HR. Bukhari: 7443, Muslim: 1016.

${ }^{44} \mathrm{Al}$-Qur'an, Qaf/50: 30

${ }^{45}$ HR. Bukhari: 6040, Muslim: 2637, Shahih Tirmidzi: 3161.

${ }^{46}$ HR. Muslim: 395, Abu Dawud: 821, Tirmidzi: 2953 dan yang lainnya.
} 
berbicara. Termasuk seluruh Al-Qur'an adalah perkataan Allah kepada Nabi-Nya Muhammad shallallahu 'alaihi wasallam.

Mengenai hakikat dan bagaimananya, maka Allahu A'lam hanya Allah yang tahu bagaimana cara Allah berbicara, karena Allah tidak jelaskan di dalam Al-Qur'an. Yang pasti diketahui bahwa Allah berbicara, dan berbicara itu difahami maknanya, yang jelas bicara itu bukan diam dan bukan juga dengan makna yang lain.

Sehingga klaim dan prasangka Ahli Kalam bahwa jika menetapkan sifat Allah dengan maknanya akan terjatuh pada tasybih adalah tidak benar. Karena kenyataanya bukan tasybih.

Syaikh Abdullah bin Muhammad Al-Ghunaiman menilai klaim Ahli Kalam bahwa itu adalah prasangka yang tidak benar, bahkan buruk sangka kepada Allah.

Beliau mengatakan, "Sebagai prasangka dari mereka bahwa lafaz-lafaz yang ada di kitabullah dan sunnah Rasul-Nya zhahirnya mengandung tasybih pada makhluk. Ini adalah buruk sangka kepada Allah, kitab-Nya dan Rasul-Nya."’

Demikian juga para Mutakallimun dalam memahami hampir semua sifat-sifat Allah. Yakni prasangka bahwa kalau menetapkan sifat Allah otomatis tasybih.

Ibnu Tamiyah dalam Risalah Tadmuriyah menyebut bahwa menetapkan sifat Allah sesuai dengan maknanya tidak mesti tasybih. Ini banyak contohnya di dalam Al-Qur'an

Allah menyebut banyak sifat-Nya dengan kata yang sama ketika menyebut makhluk-Nya.

Seperti kata Istawa,

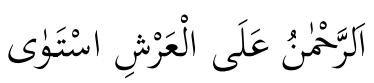

(artinya), "Yang Maha Pengasih, yang bersemayam di atas 'Arsy.",

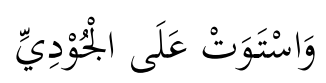

(artinya), "dan kapal itupun berhenti (menetap) di atas gunung Judi."49

Kata Ra'uf dan Rahim,

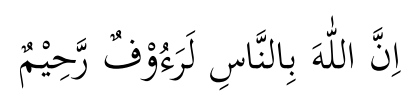

${ }^{47}$ Abdullah bin Muhammad Al-Ghunaiman, Syarah Kitab At-Tauhid min Shahih Al-Bukhari, Vol. 1 (Riyadh: Dar Al-'Ashimah, 1428 H) h. 107.

${ }^{48}$ Al-Qur'an, Thaha/20: 5.

${ }^{49} \mathrm{Al}-\mathrm{Qur}$ 'an, Hud/11: 44. 
(artinya), "Sungguh, Allah Maha Pengasih, Maha Penyayang kepada manusia."

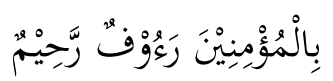

(artinya), "(Muhammad itu) penyantun dan penyayang terhadap orang-orang yang beriman." 51

Kata Al-Hayyu,

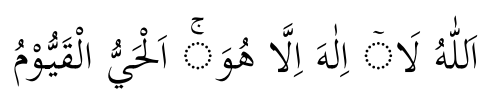

(artinya), "Allah, tidak ada tuhan selain Dia. Yang Mahahidup, Yang terus menerus mengurus (makhluk-Nya).",52

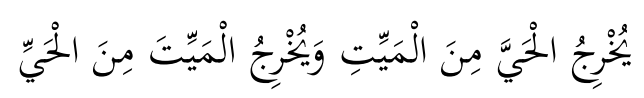

(artinya), "Dia mengeluarkan yang hidup dari yang mati dan mengeluarkan yang mati dari yang hidup."

Kata Yastahyi (malu),

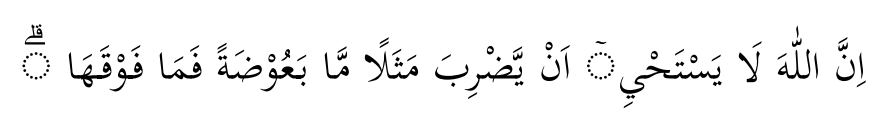

(artinya), "Sesungguhnya Allah tidak malu membuat perumpamaan seekor nyamuk atau yang lebih kecil dari itu." 54

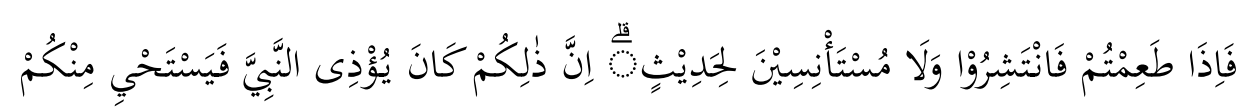

(artinya), "Dan apabila kamu selesai makan, keluarlah kamu tanpa memperpanjang percakapan. Sesungguhnya yang demikian itu adalah mengganggu Nabi sehingga dia (Nabi) malu kepadamu (untuk menyuruhmu keluar)."

Dan masih banyak lagi yang disebutkan oleh Ibnu Taimiyah dalam Risalah-nya.

Menurutnya, kata-kata yang sama ini menunjukkan ada cakupan makna yang sama (Al-Qadru Al-Musytarak) namun ketika di-idhafah-kan (disandarkan) kepada yang lain tentu akan berbeda hakikatnya. Seperti kaki manusia dan kaki gajah. Antara kaki manusia dan kaki gajah jelas perbedaannya. Namun disini ada Al-Qadru Al-Musytarak (cakupan makna yang sama). Meskipun hakekatnya

\footnotetext{
${ }^{50} \mathrm{Al}-\mathrm{Qur}$ 'an, Al-Baqarah/2: 143

${ }^{51}$ Al-Qur'an, At-Taubah/9: 128

${ }^{52} \mathrm{Al}-\mathrm{Qur}$ 'an, Al-Baqarah/2: 255.

${ }^{53}$ Al-Qur'an, Ar-Rum/30: 19.

${ }^{54} \mathrm{Al}-\mathrm{Qur}$ 'an, Al-Baqarah/2: 26.

${ }^{55}$ Al-Qur'an, Al-Ahzab/33: 53.
} 
berbeda, namun keduanya tetap bermakna kaki. Dan tidak mungkin bermakna lain menjadi kepala misalnya.

Begitu pula antara Allah dengan makhluk-Nya. Allah memakai kata yang sama ketika menyebut diri-Nya dan juga makhluk-Nya. Hal ini menunjukkan ada cakupan makna yang sama. Namun jika disandarkan kepada Allah maka hakekatnya,

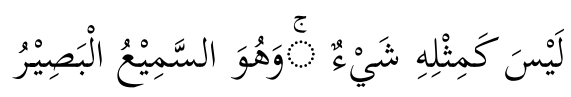

(artinya), "Tidak ada sesuatu pun yang serupa dengan Dia. Dan Dia Maha Mendengar, Maha Melihat."

\section{Tawahhum Pada Al-Lawazim Al-Bathilah}

Dalam Teologi Salafiyah, Tawahhum pada Al-Lawazim Al-Bathilah ini juga merupakan hal pokok yang menyebabkan Ahli Kalam terjatuh dalam beragam kekeliruan. Yakni adanya prasangka jika menetapkan sifat Allah berarti otomatis menetapkan konsekuensi dari sifat tersebut.

Misalnya, sifat Al-'Uluw (ketinggian Dzat Allah), Al-Istiwa'(Allah bersemayam di atas 'Arsy) dan An-Nuzul (Allah turun di sepertiga malam terakhir ke langit dunia).

Ahli Kalam menyebut bahwa tidak mungkin Allah berada di atas dengan DzatNya (sifat Al-'Uluw Adz-Dzatiyyah). Ini menjadi keyakinan Asy'ariyah Muta'akhirin seperti Al-Ghazali dan yang lainnya.

Al-Ghazali mengatakan, "Mereka (Ahlussunnah) mengetahui bahwa arah ini dinafikan, karena ia sarat dengan jismiyyah." ${ }^{\circ 7}$

Al-Sanusi dalam matan Umm Al-Barahin mengatakan, "Dan di antara yang mustahil bagi Allah adalah dua puluh sifat.. atau berada dalam arah tertentu," salah satu pensyarah matan ini kemudian menjelaskan, "Maksudnya adalah mustahil bagi Allah berada dalam suatu arah dengan berada di atas 'Arsy atau di bawahnya, atau di kanannya, atau di kirinya..." 58

Selain itu mereka menafikan juga bahwa Allah turun ke langit dunia di setiap sepertiga akhir malam dengan menta'wil bahwa yang turun adalah malaikat-Nya atau rahmat-Nya.

Al-Ghazali mengatakan, "Terkait disandarkannya sifat nuzul kepada-Nya, dan ini adalah majaz. Hakikatnya adalah disandarkan kepada salah satu malaikat.,"59

\footnotetext{
${ }^{56} \mathrm{Al}-\mathrm{Qur}$ 'an, Asy-Syura/42: 11.

${ }^{57}$ Al-Ghazali, Al-Iqtishad, h. 48

${ }^{58} \mathrm{Ahmad}$ Isa Al-Anshari, Syarah Umm Al-Barahin (Beirut: Al-Maktabah Al-Tsaqafiyah, t.t.), h. 24

${ }^{59}$ Al-Ghazali, Al-Iqtishad, h. 39.
} 
Ta’wil ini kurang tepat jika dikatakan Malaikat yang turun. Karena tidak mungkin Malaikat mengatakan, "Siapa yang meminta pada-Ku niscaya Aku berikan, siapa yang berdoa kepada-Ku niscaya Aku ijabah, siapa yang memohon ampun pada-Ku niscaya Aku ampuni." Ungkapan seperti ini tidak boleh dikatakan kecuali Allah Ta'ala.

Kemudian, menurut Ibnu Taimiyah, jika Malaikat yang menyeru mestinya ia mengucapkan, "Allah memerintahkan ini. Begitu juga jika seorang raja memerintahkan penyerunya untuk mengumumkan, maka penyeru itu akan mengatakan, wahai sekalian manusia! Sultan memerintahkan ini, melarang ini, dan tidak mungkin mengatakan, saya perintahkan ini, saya melarang ini, siapa yang melakukannya akan dihukum." 60

Kemudian mereka membawa makna sifat Al-Istiwa' kepada makna yang lain (Ta'wil). Dengan mengatakan Istawa bermakna Istaula (menguasai).

Ibnu Jama'ah mengatakan, "Firman Allah Ta'ala, Istawa, maknanya adalah AlIstila' dan menguasai. Bukan duduk dan bukan pula menetap." 61

Para tokoh awal Asy'ariyah mengosongkan maknanya (Tafwidh Al-Ma'na). Mereka mengatakan bahwa Istiwa' adalah suatu perbuatan yang Allah lakukan di 'Arsy yang Ia beri nama Istiwa'. 62

Adapun Mu’tazilah dan Jahmiyah sudah jelas menolak semua sifat Allah.

Mereka khawatir menetapkan sifat-sifat ini, karena difahami oleh Ahli Kalam bahwa jika menetapkan sifat-sifat Allah ini berarti konsekuensinya Allah terbatas, Allah butuh tempat, Allah berada di dalam alam, di dalam langit, makhluk-Nya meliputi-Nya dan makhluk-Nya lebih besar dari Allah Swt. ${ }^{63}$

Ibnu Jama'ah mengatakan, "Dan Dia Ta'ala Al-Ghani Al-Muthlaq tidak butuh pada selain-Nya. Dahulu Allah ada tanpa waktu dan tempat. Dan sekarang Ia berada seperti sebelumnya. (Istawa dengan makna menetap-pent)mengharuskan keberadaan-Nya terbatas dan terukur. Dan setiap yang terbatas dan yang terukur itu adalah jism. Dan setiap jism itu tersusun saling membutuhkan pada tiap bagiannya."

Inilah juga yang difahami oleh istri Jahm bin Shafwan.

Al-Ashma'i meriwayatkan, bahwa istri Jahm datang lalu seseorang berkata padanya, "Allah berada di atas Arsy-Nya," istri Jahm menimpali, "Mahdud 'ala

\footnotetext{
${ }^{60}$ Ibnu Taimiyah, Syarh Hadits Al-Nuzul (Beirut: Al-Maktab Al-Islami, 1402 H), h. 36-37.

${ }^{61}$ Ibnu Jama'ah, Idhah Al-Dalil fi Qat'i Hujaji Ahl Al-Ta'thil (Cairo: Dar Al-Salam, 1410 H), h. 103-104.

${ }^{62}$ Abu Bakar Ahmad bin Al-Husain bin Ali Al-Baihaqi, Al-Asma' wa Al-Shifat (Beirut: Dar Al-Kutub Al'Ilmiiyyah, t.t.), h. 564.

${ }^{63}$ Al-Tharifi, Al-Maghribiyah fi Syarh Al-'Aqidah, h. 105.

${ }^{64}$ Ibnu Jama'ah, Idhah Al-Dalil fi Qat'i, h. 103-104.
} 
Mahdud, sesuatu yang terbatas berada pada sesuatu yang terbatas." Al-Ashma'i kemudian mengatakan, "Ia (istri Jahm) telah kafir dengan perkataan ini." 65

Atas prasangka ini sebagian mutakallimun mencap kelompok Salafiyah sebagai mujassimah dan musyabbihah.

Ibnu Taimiyah menyebut bahwa Nufat Al-Shifat (yang menolak sifat-sifat Allah) memberi nama pada orang yang menetapkan sifat-sifat Allah dengan sebutan mujassimah. Karena mereka meyakini bahwa sifat-sifat tersebut tidak mungkin ada kecuali pada Al-Jism yang bermakna anggota badan. Olehnya itu mereka melempar tuduhan mujassimah dan musyabbihah pada para pengikut salaf. ${ }^{66}$

Prasangka Ahli Kalam dengan konsekuensi-konsekuensi tersebut tidak benar, baik ditimbang dengan akal manusia maupun dengan dalil syar'i. ${ }^{67}$

Jika dilihat dari akal manusia tidak mungkin sesuatu yang kecil meliputi sesuatu yang lebih besar. Karena itu, tidak ada dalam fikiran manusia bumi akan meliputi langit (langit berada di dalam bumi) atau semut akan meliputi gunung (gunung ada di dalam semut). Sehingga ini tidak mungkin terjadi pada Allah, karena Allahu Akbar. Allah mahabesar dari segalanya.

Di dalam hadis disebutkan,

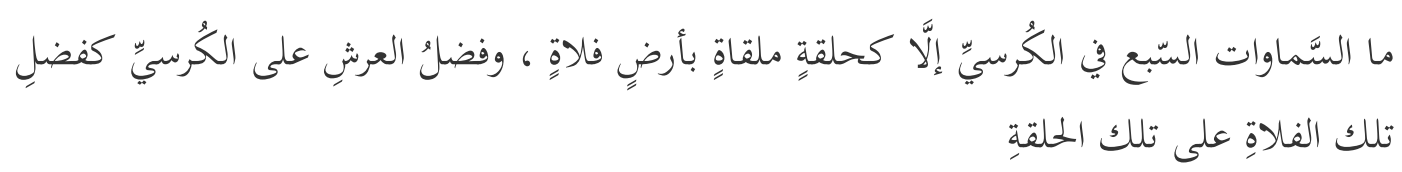

"Tidaklah tujuh langit dibandingkan Al-Kursi melainkan seperti cincin yang dilempar di tengah tanah lapang, sedangkan ukuran Al-Arsy dibandingkan AlKursi seperti tanah lapang tersebut dibandingkan dengan cincin tadi." 68

Dalam sebagian lafaz pada riwayat lain disebutkan, "Dan tidaklah semua itu dalam genggaman Allah 'Azza wa Jalla melainkan seperti satu biji atau yang lebih kecil lagi di tangan salah seorang dari kalian, dan itulah firman Allah (yang artinya) Dan bumi semuanya Aku genggam di hari kiamat. ${ }^{69,}$

Dari sini, sangat mungkin untuk difahami bahwa menjelaskan sesuai dengan yang Allah jelaskan tentang bersemayam-Nya di atas 'Arsy bukan berarti bahwa Allah butuh tempat. Karena itu merupakan lawazim bathilah, konsekuensi yang tidak benar dan tidak layak untuk Allah. Allah berfirman,

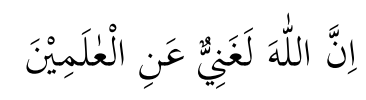

\footnotetext{
${ }^{65}$ Al-Hafizh Syamsuddin Muhammad bin Utsman Al-Dzahabi, Al- 'Uluw Li Al- 'Aliy Al-Ghaffar fi Idhah Shahih Al-Akhbar min Saqimiha (Riyadh: Maktabah Adhwa' Al-Salaf, 1416 H), h. 159.

${ }^{66}$ Al-Ghunaiman, Syarah Kitab Tauhid, 1. no. 1, h. 108.

${ }^{67}$ Al-Tharifi, Al-Maghribiyah fi Syarh Al-'Aqidah, h. 112.

${ }^{68}$ Shahih Ibnu Hibban 361.

${ }^{69}$ Al-Qur'an, Az-Zumar/39: 67.
} 
(artinya), "Sesungguhnya Allah Mahakaya, tidak memerlukan sesuatu dari seluruh alam semesta."70

Sedangkan jika dilihat dari dalil syar'i, Allah tidaklah serupa dengan sesuatu apapun terhadap Dzat-Nya, sebagaimana firman Allah, "Dia tidaklah serupa dengan sesuatu apapun." Nya wajib diimani dan ditetapkan dengan maknanya bahwa sifat itu ada, tidak menafikannya dan tidak dimaknai dengan yang lainnya. Serta berhenti (tawaqquf) berbicara dan membayangkan konsekuensinya yang menjurus pada tasybih.

Alasannya adalah jika Dzat-Nya yang mahaagung tidak serupa dengan sesuatu apapun, maka bagaimana mungkin akan serupa sifat-Nya dan juga konsekuensi sifat-Nya dengan sesuatu yang lain?!

Manusia jika disebutkan sesuatu padanya pasti akan berusaha mengumpulkan informasi dan gambaran dalam otaknya terkait yang dibicarakan, lalu merekareka dan mengkonstruksi informasi tersebut dalam suatu bentuk dalam fikirannya.

Padahal, Allah itu tidak diukur, tidak dibandingkan, dan tidak dibayangkan dengan sesuatu apapun. Mau difikir bagaimanapun tidak akan ketemu. Karena memang Allah tidak ada bandingan-Nya. Lam Yakun Lahu Kufuwan Ahad. ${ }^{72}$ Tidak ada yang serupa dengan-Nya. Laisa Kamitslihi Syai'un. ${ }^{73}$

Ibnu Abdil Barr mengatakan, "Kita dilarang bertafakkur tentang Allah, dan kita diperintahkan bertafakkur tentang ciptaan-Nya yang menunjukkan tentang Dia."74

Al-Tharifi mengatakan, "Wajib menahan akal dan fikiran agar tidak dibiarkan berfikir kaifiyyah Dzat Allah dan sifat-sifat-Nya. Karena alam fikiran pasti akan menyerupakan, membuat permisalan dan mengkonstruksi kaifiyyah. Tidak mungkin akal menciptakan gambaran baru pada suatu objek yang belum pernah dia lihat sebelumnya. Jika ia melakukan itu sebenarnya ia hanya gambaran yang tersusun dari beberapa objek yang ia satukan. Karena masing-masing fikiran pasti akan menggambarkan sesuatu yang ghaib dengan sesuatu yang pernah ia lihat. Sehingga akan berbeda antara satu orang dengan yang lainnya dalam memikirkan satu objek yang sama karena perbedaan data yang terinput di masing-masing otak. Karena itulah ulama salaf melarang berdebat tentang Allah, nama-nama-Nya dan sifat-sifat-Nya." 75

Fatalnya, Ahli Kalam berfikir ke makhluk jika disebut sifat Allah.

\footnotetext{
${ }^{70} \mathrm{Al}-\mathrm{Qur}$ 'an, Al-'Ankabut/29: 6.

${ }^{71} \mathrm{Al}$-Qur'an, Asy-Syura/42: 11.

${ }^{72} \mathrm{Al}-\mathrm{Qur}$ 'an, Al-Ikhlas/112: 4.

${ }^{73} \mathrm{Al}-\mathrm{Qur}$ 'an, Asy-Syura/42: 11.

${ }^{74}$ Ibn Abd Al-Barr, Jami’ Bayan Al-'Ilm Wa Fadhlihi (Beirut: Dar Al-Kutub Al-Ilmiyah, t.t), h. 363.

${ }^{75}$ Al-Tharifi, Al-Maghribiyah fi Syarh Al-'Aqidah, h. 87.
} 
Terlebih jika disebut shifat al-dzatiyyah al-khabariyah. Al-Ghazali mangatakan tentang sifat $A l-A s h a b i$," "Kami telah memeriksa hati kaum mukminin dan kami tidak dapati ada jari-jari disitu maka diketahuilah bahwa itu adalah kiasan dari qudrah dimana ia menjadi rahasia jari dan ruhnya yang tersembunyi." ${ }^{\text {"76 }}$

Ibnu Jama'ah juga berfikir ke makhluk ketika disebut Ashabi' Al-Rahman, dan karena itu tidak mungkin terjadi sehingga perlu ditakwil, "Ketika membawa makna hadis kepada anggota badan yang sudah ma'ruf dari kita maka itu mustahil bagi Allah Ta'ala, karena akan bermakna jismiyyah. Sehingga wajib menta'wilnya."77

Jika saja alam fikiran Ahli Kalam terbebas dari perbanding-perbandingan semacam itu, pasti mereka tidak akan melakukan ta'thil, ta'wil dan tafwidh.

Ibnu Taimiyah menyebut pola fikir ini menjadikan seseorang mengingkari sifatsifat Allah, "Dengan klaimnya ia berargumen untuk mengingkari sesuatu yang $R a b b$ sifati dan namai sendiri untuk diri-Nya dengan mengatakan bahwa harus seperti ini jika Ia memiliki ini." 78

Teologi Salafiyah memahami Sifat-sifat Allah dengan menetapkan sifat tersebut, meyakini maknanya, lalu menyerahkan kaifiyahnya/hakikatnya kepada Allah dan berhenti membayangkan apapun untuk mencari-cari hakikatnya seperti apa, agar tidak terjatuh pada lawazim bathilah, konsekuensi yang tidak benar dan tidak layak untuk Allah Subhanahu Wa Ta'ala.

\section{Ghuluw Dalam Melakukan Tanzih dan Tawahhum Ta'zhim}

Berikutnya adalah ghuluw (terlalu berlebihan) dalam melakukan tanzih (mensucikan Allah) dengan berprasangka bahwa apa yang dilakukannya merupakan bentuk mengagungkan Allah (tawahhum ta'zhim). ${ }^{79}$

Sebelum mazhab tafwidh muncul, banyak Ahli Bid'ah terjatuh dalam tasybih seperti yang dilakukan oleh As-Saba'iyyah ${ }^{80}$ dan Rafidhah $^{81}$,

Hisyam bin Salim Al-Jawaliqi dari kalangan Rafidhah mengklaim bahwa bentuk tuhannya seperti bentuk manusia, setengah bagian atasnya berongga dan setengah bagian bawahnya padat.

Dawud Al-Jawaribi menyifati tuhannya memiliki semua anggota badan manusia kecuali kemaluan dan janggut. ${ }^{82}$

\footnotetext{
${ }^{76}$ Abu Hamid Al-Ghazali, Qawa'id Al- 'Aqa'id (Beirut: 'Alam Al-Kutub, 1405 H), h. 167-168

${ }^{77}$ Ibnu Jama' ah, Idhah Al-Dalil fi Qat'i, h. 179.

${ }^{78}$ Abdul Aziz bin Baz, Ta'liqat Samahat Al-Sayikh Al- 'Allamah Abdil Aziz bin Baz 'Ala Al-Risalah Al-

Hamawiyah Al-Kubro (Riyadh: Muassasah Abdul Aziz bin Baz Al-Khairiyah, 1435 H), h. 79.

${ }^{79}$ Al-Tharifi, Al-Maghribiyah fi Syarh Al- 'Aqidah, h. 98.

${ }^{80}$ Pengikut Abdullah bin Saba' yang muncul di zaman Utsman bin Affan lalu di zaman Ali bin Abi Thalib.

${ }^{81}$ Muhammad Bakarim Muhammad Ba'abdullah, Wasathiyatu Ahlis Sunnah Baina Al-Firaq (Madinah: Maktabah Al-'Ulum wa Al-Hikam, 1437 H), h. 359-361.
} 
Atas munculnya pemahaman tasybih dan tajsim semacam ini dan dengan klaim ingin mengagungkan Allah, sebagian kelompok memilih jalan ta'thil kulli, menolak seluruh sifat-sifat Allah. Meskipun ta'thil kulli ini telah ada sejak lama.

Ketika disebutkan penjelasan tentang Jahmiyah kepada Abdurrahman bin Mahdi bahwa mereka menolak hadis-hadis tentang nuzul, al-yad dan al-rijl, lalu mereka mengatakan, "Allah lebih agung dari sekedar disifati dengan sesuatu!" beliau kemudian berkata, "Kaum tersebut telah hancur dari sisi ini." 83

Disini Jahmiyah menyangka bahwa cara mengagungkan Allah adalah tidak menyifatinya dengan sesuatu apapun. Padahal kesalahan-kesalahan yang terjadi terhadap interpretasi sifat-sifat Allah dari kalangan Musyabbihah tidak lantas membuat kita menafikan sifat-Nya.

Imam Ahmad mengatakan, "Kita tidak meniadakan dari-Nya satu sifat dari sifatsifat-Nya dikarenakan adanya kekeliruan yang terjadi." 84

Kemudian tersebar juga mazhab ta'wil dan tahrif seperti yang dilakukan oleh Mu'tazilah dan yang lainnya.

Fenomena ini membuat sebagian Ahli Kalam menyangka bahwa tafwidh adalah solusi dari itu semua.

Dengan harapan mereka bahwa tafwidh ini bisa menyelamatkan orang awam dari ketergelinciran semacam itu seperti yang dikatakan oleh Al-Ghazali. ${ }^{85}$

Namun sebelumnya, perlu dibedakan antara bentuk tafwidh menurut Salafiyah dengan yang lainnya. Tafwidh yang benar dalam Teologi Salafiyah adalah tafwidh al-kaifiyah, yakni menyerahkan ilmu tentang kaifiyahnya kepada Allah. Namun maknanya diketahui.

Dan inilah tujuannya Allah mensifati diri-Nya, agar diketahui maknanya lalu mentadabburi sifat-sifat-Nya dengan segala keagungan dan kemuliaan-Nya.

Sedangkan jalan yang ditempuh oleh sebagian Ahli Kalam adalah tafwidh alma'na. Menyerahkan maknanya kepada Allah.

Sebagian Ahli Kalam tersebut menyangka bahwa dengan menyerahkan maknanya kepada Allah menjadi jalan keluar dari kesalahan-kesalahan yang dilakukan oleh kebanyakan ahlu bid'ah pada zaman tersebut.

Mazhab tafwidh sendiri mulai tersebar di abad ketiga hijriyah sebagaimana disebutkan oleh Ad-Darimi dalam kitabnya, "Ar-Radd 'Ala Bisyr Al-Marisiy". Pemikiran seperti ini bersumber dari Kullabiyah. Lalu setelahnya oleh Abu

\footnotetext{
${ }^{82}$ Muhammad Ba'abdullah, Wasathiyah Ahlis Sunnah, h. 360.

${ }^{83}$ Abu Ya'la Muhammad bin Husain Ibn Al-Farra', Ibthal Al-Ta'wilat Li Akhbar Al-Shifat, Juz 1 (Kuwait: Dar Ilaf Al-Dauliyah, 1407 H), h. 53.

${ }^{84}$ Ibnu Quddamah Al-Maqdisi, Itsbat Shifat Al-'Uluw (Damaskus: Mu'assasah 'Ulum Al-Qur'an, 1409 H), h. 25 .

${ }^{85}$ Al-Tharifi, Al-Maghribiyah fi Syarh Al-'Aqidah, h. 97.
} 
Manshur Al-Maturidi di Khurasan dan Abu Al-Hasan Al-'Asy'ari di Irak dalam risalahnya, "Risalah Ila Ahl Ats-Tsagr" yang ditulis sebelum kitabnya, "AlIbanah."

Tujuannya ingin berada di antara dua kubu yang berseberangan, antara yang menolak sifat-sifat Allah (Mu'aththilah) dan yang menyerupakan Allah dengan makhluk-Nya (Musyabbihah).

Para ulama Salafiyah menilai bahwa tafwidh seperti ini hakekatnya adalah menolak sifat-sifat Allah (ta'thil) pada akhirnya. ${ }^{86}$ Atau merupakan salah satu bentuk ta'thil. ${ }^{87}$

Berikut kutipan contoh tafwidh al-ma'na,

Imam Al-Baihaqi mengatakan, ${ }^{88}$ "Adapun Al-Ityan dan Al-Maji' menurut perkataan Abu Al-Hasan Al-'Asy'ari, Allah Ta'ala mengadakan sebuah perbuatan di hari kiamat yang Ia beri nama Ityan dan Maji'. Tidak bergerak dan tidak pindah"

Terkait dengan sifat $A n-N u z u l$, ia mengatakan "Begini juga yang ia katakan terkait riwayat-riwayat tentang nuzul. Bahwa yang dimaksud adalah suatu perbuatan yang Allah adakan di langit dunia setiap malam yang Ia beri nama nuzul. Tidak ada pergerakan dan tidak ada perpindahan."

Model tafwidh seperti ini tidak menetapkan sifat yang Allah maksudkan dan bahkan menafikan hakikat makna sifat tersebut.

Imam Abdul Ghani Al-Maqdisi ketika menetapkan sifat Nuzul beliau mengatakan, "Tanpa tanzih (mensucikan Allah) yang berujung pada menafikan hakikat nuzul." 89

Perkataan Imam Malik dan Rabi'ah yang masyhur tentang Istiwa' sama dengan ucapan ulama-ulama yang lain ketika mengatakan, Amirruha kama ja'at bila kaif, bacalah sebagaimana ia datang tanpa bagaimana.

Ibnu Taimiyah mengatakan bahwa yang mereka maksudkan adalah menafikan kaifiyahnya, bukan menafikan hakikat sifat. "Jika saja kaum tersebut beriman hanya pada lafaz tanpa memahami maknanya yang layak untuk Allah, niscaya mereka tidak mengatakan Istiwa' ma'lum (sudah diketahui) dan kaifiyahnya tidak diketahui. Lalu ketika mereka mengatakan Amirruha kama ja'at bila kaif maka Istiwa' pada saat itu menjadi tidak diketahui, bahkan ia majhul, kedudukannya seperti huruf-huruf dalam kamus."90

\footnotetext{
${ }^{86}$ Al-Tharifi, Al-Maghribiyah fi Syarh Al-'Aqidah, h. 94.

${ }^{87}$ Abd Al-Akhir Al-Ghunaimi, Aqidat Al-Hafizh Ibn Katsir Baina Al-Tafwidh wa Al-Ta'wil (Dammam: Dar AlAkhla', 1415 H), h. 11.

${ }^{88}$ Al-Baihaqi, Al-Asma' wa Al-Shifat h. 564.

${ }^{89}$ Taqiyuddin Ibn Abd Al-Qadir Al-Hilali, Sabil Al-Rasyad fi Hadyi Khair Al- Ibad, Juz 5 (Amman: Dar AlAtsariyah, 1427 H), h. 22.

${ }^{90}$ Abdul Aziz bin Baz, Ta'liqat Samahat Al-Syaikh, h. 76.
} 
Jika demikian, maka iman terhadap ayat-ayat tentang sifat Allah hanya mengimani huruf-hurufnya saja. Akhirnya bahasa arabnya Al-Qur'an menjadi tak bermakna.

Dan ini jelas menyelisihi tujuan dari diturunkannya Al-Qur'an.

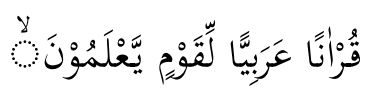

(artinya), "Qur'an yang berbahasa arab bagi orang-orang yang mengetahui.", ,

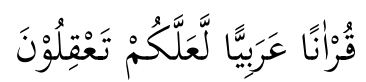

(artinya), "Qur' an yang berbahasa arab agar kalian berfikir.",

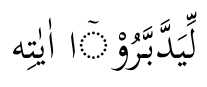

(artinya), "Agar mereka mentadabburi ayat-ayat-Nya."93

Teologi Salafiyah meyakini bahwa sifat-sifat tersebut memiliki makna dan difahami maknanya, karena jika tanpa makna akan menjadi sia-sia ketika Allah dan Rasul-Nya menyebutkan banyak sifat mengenani diri-Nya di dalam AlQur'an maupun hadis?!

Memahami makna yang dimaksud adalah seperti contoh berikut ini.

Bahwa ketika Allah mengatakan,

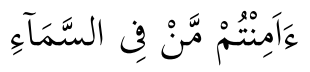

(artinya), "Apakah kalian beriman dengan yang berada di atas langit."

Dzat Allah berada di atas langit, bukan di dalam langit dan bukan pula di bawah langit.

Ketika Allah mengatakan,

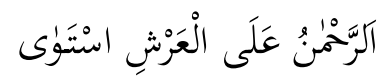

(artinya), "Ar-Rahman bersemayam di atas Arsy." 95 Bahwa Allah berada di atas Arsy bersemayam, bukan lari.

${ }^{91} \mathrm{Al}-\mathrm{Qur}$ 'an, Fushilat/41: 3.

${ }^{92} \mathrm{Al}-\mathrm{Qur}$ 'an, Yusuf/12: 2.

${ }^{93}$ Al-Qur'an, Shad/38: 29.

${ }^{94} \mathrm{Al}-\mathrm{Qur}$ 'an, Al-Mulk/67: 16.

${ }^{95} \mathrm{Al}-\mathrm{Qur}$ 'an, Thaha/20: 5. 
Dan ketika Allah disebutkan oleh Rasulullah bahwa Allah turun ke langit dunia di setiap sepertiga akhir malam difahami dengan jelas bahwa turun itu bukan ke atas.

Syaikh Abdul Aziz Bin Baz mengatakan, "Al-Sami' diketahui maknanya yaitu mendengar suara, Al-Bashar itu melihat sesuatu, Al-'Ilmu itu mengetahui sesuatu dan memahaminya, Al-Qudrah kebalikan dari lemah. Makna-makna ini sudah diketahui. Namun tidak diketahui kaifiyahnya kecuali Dia Jalla wa' Ala. Karena itulah Malik, Rabi'ah, Ummu Salamah dan para Salaf setelah mereka mengatakan, 'Istiwa' sudah diketahui maknanya, namun hakikatnya tidak diketahui, mengimaninya wajib dan bertanya tentang itu adalah bid'ah'."96

Makna tersebut sesuai dengan lafaznya, tanpa ada pembiasan makna, pengalihan makna dan pengosongan makna.

Untuk memahami sebuah lafaz dengan maknanya tanpa mengetahui hakikatnya, Ibnu Taimiyah menjelaskannya dengan mencontohkan surga.

Rasulullah menyebutkan tentang sifat-sifat surga, bahwa di surga ada pohon, ada istana, ada buah-buahan, ada sungai. Difahami maknanya, bahwa pohon itu sudah jelas seperti yang difahami, dan pasti bukan mobil. Jika disebut istana dalam surga difahami dengan jelas bahwa itu istana, bukan gubuk. Dan seterusnya.

Adapun hakikatnya seperti apa Allahu A'lam. Rasulullah shallallahu alaihi wasallam dalam hadis Qudsi meriwayatkan firman Allah ketika menyebut tentang surga,

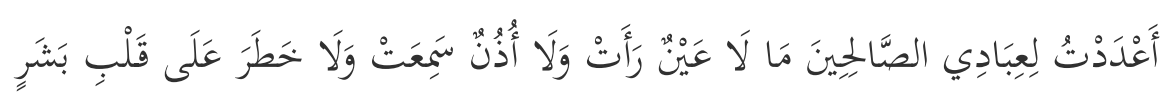

(artinya), “Aku menyediakan untuk hamba-hamba-Ku yang sholeh sesuatu yang tidak pernah dilihat oleh mata, tidak pernah didengar oleh telinga dan tidak pernah terbersit di hati seorang manusia pun." 97

Semua gambaran surga yang disebutkan maknanya jelas, namun hakikatnya belum diketahui oleh manusia.

Pemahaman terhadap makna sifat sebatas pada makna bahasa, dan bukan tentang hakikatnya. Dan sangat keliru jika menjelaskan sifat Allah dengan nalar manusia, atau menambahkan penjelasan-penjelasan yang tidak perlu dengan penjelasan baru yang tidak terdapat dalam syariat.

Karena itulah, Imam Ahmad bin Hanbal pernah marah dan menegur tukang cerita yang menjelaskan tentang hadis nuzul dengan mengatakan bahwa turunnya Allah tanpa zawal, tidak pindah dan tanpa perubahan keadaan. Mendengar ini, Imam Ahmad marah dan mengajak anaknya, Abdullah, "Mari kita ke pembohong itu,"

\footnotetext{
${ }^{96}$ Abdul Aziz bin Baz, Ta'liqat Samahat Al-Sayikh, h. 63-64.

${ }^{97}$ HR. Bukhari 3244, HR. Muslim 2824 dari riwayat Abu Hurairah.
} 
lalu ia berkata pada tukang cerita tersebut, "Rasulullah lebih cemburu terhadap Rabbnya darimu, katakanlah sesuai yang dikatakan oleh Rasulullah shallallahu 'alaihi wasallam." Lalu Imam Ahmad pergi. ${ }^{98}$

\section{Tidak Memahami Bahasa Arab Sesuai Konteksnya (Siyaq)}

Seperti yang dipaparkan di poin sebelumnya, bahwa Al-Qur'an diturunkan untuk difahami dan ditadabburi. Namun memahaminya harus sesuai dengan pemahaman bahasa yang baik. Dalam hal ini, wajib memahami bahasa arab di dalam Al-Qur'an dengan pemahaman yang komprehensif dan sesuai kaidahkaidah bahasa arab. Yakni dengan memahami konteks dan bangunan kalimatnya, juga melihat dalil-dalil lain untuk menemukan makna yang tepat.

Jika kita melihat satu kata dalam kamus bahasa arab, kita akan menemukan beberapa pengertian dari kata yang dimaksud. Karena satu kata akan melahirkan beberapa pengertian yang berbeda tergantung dari konteks dalam bangunan kalimat.

Sebenarnya melihat tiga poin di atas sudah cukup untuk mengetahui sebab ragam interpretasi Ahli Kalam dalam memahami sifat-sifat Allah. Intinya mereka mengklaim jika menetapkan sifat-sifat Allah sesuai dengan maknanya akan terjatuh pada tasybih pada sifat tersebut (poin pertama) atau pada konsekuensi dari sifat tersebut, lawazim bathilah (poin kedua). Dan dilakukan dengan klaim untuk mensucikan dan mengagungkan Allah (poin ketiga).

Namun kalau melihat dari penggunaan dan pemahaman bahasa arab sesuai konteksnya, Ahli Kalam membuang pemahaman seperti ini dan justru lari pada ta'wil yang mereka inginkan. ${ }^{99}$

Syaikh Muhammad bin Shalih Al-Utsaimin, ulama kelompok Salafiyah kontemporer memberikan contoh penerapan dalam memahami bahasa arab sesuai konteksnya.

Dalam Al-Qur'an disebutkan,

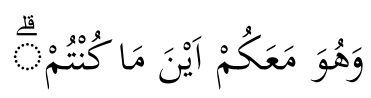

(artinya), "Dan Dia bersama kalian dimanapun kalian berada."100

Juga firman Allah,

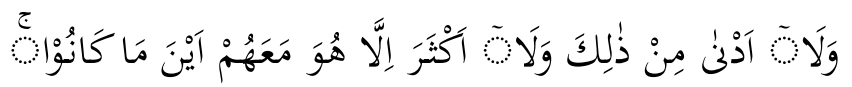

\footnotetext{
${ }^{98}$ Al-Tharifi, Al-Maghribiyah fi Syarh Al- 'Aqidah, h. 105.

${ }_{99}$ Al-Utsaimin, Al-Qawaid Al-Mutsla, h. 65-100, disini Syaikh Muhammad bin Shalih Al-'Utsaimin memaparkan 15 contoh dalam memahami teks-teks syariat yang berbicara mengenai sifat-sifat Allah sesuai dengan konteks bahasa arab.

${ }^{100} \mathrm{Al}$-Qur'an, Al-Hadid/57: 4.
} 
(artinya), "Dan tidaklah jumlah yang lebih sedikit dari itu maupun jumlah yang lebih banyak melainkan Dia bersama mereka dimanapun mereka berada."101

Sebagian Ahli Kalam mengatakan bahwa Allah bersama dengan makhluk-Nya menyatu dengan mereka. Keyakinan ini disebut dengan Hululiyah. Dicetuskan oleh para pendahulu Jahmiyah, juga Ibnu Arabi dalam al-Futuhat al-Makkiyah serta Ibnul Faridh. ${ }^{102}$

Makna yang benar dari ayat di atas bahwa Allah bersama makhluk-Nya adalah kebersamaan yang tidak mengharuskan menyatu atau berada di sampingnya. Namun Allah bersama mereka dengan ilmu-Nya. Dalilnya adalah firman Allah secara lengkap di ayat keempat surat Al-Hadid.

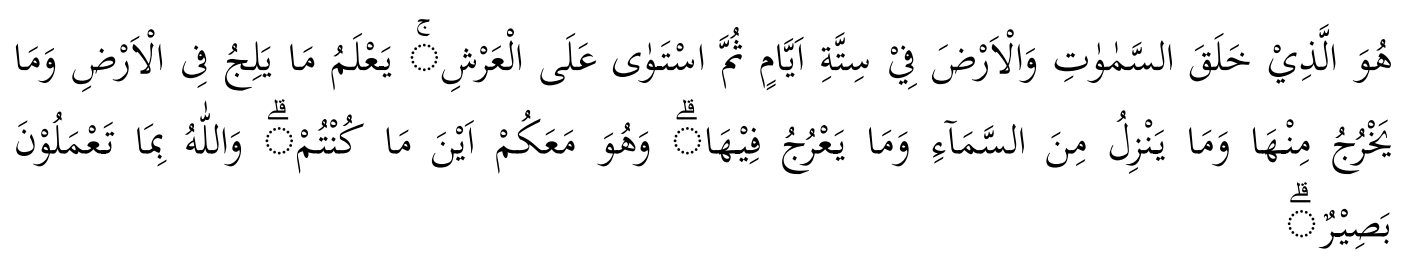

(artinya), "Dialah yang menciptakan langit dan bumi dalam enam hari kemudian bersemayam di atas 'Arsy, Dia mengetahui apa yang masuk di bumi dan apa yang keluar darinya dan apa yang turun dari langit maupun yang naik kepadanya. Dan Dia bersama kalian dimanapun kalian berada. Dan Allah maha melihat terhadap apa yang kalian lakukan."

Al-Utsaimin mengatakan, "Zahir ayat ini bermakna bahwa kebersamaan yang dimaksud adalah ilmu-Nya terhadap hamba-hamba-Nya, penglihatan-Nya atas amalan-amalan mereka, bersama dengan itu Allah berada di atas mereka bersemayam di atas 'Arsy. Tidak menyatu dengan mereka dan juga tidak bersama dengan mereka di bumi. Karena jika tidak demikian maknanya, maka akhir ayat akan berkontradiksi dengan awal ayat yang menyatakan ketinggian Dzat Allah dan bersemayam-Nya di atas 'Arsy." 103

Kedua hal ini bisa terjadi dan bukan suatu kontradiksi. Allah bersemayam di atas 'Arsy-Nya dan Allah bersama hamba-Nya dengan ilmu-Nya. Karena Allah mengumpulkan dua hal tersebut dalam satu ayat. Dan tidak ada satupun yang bertentangan di dalam Al-Qur'an,

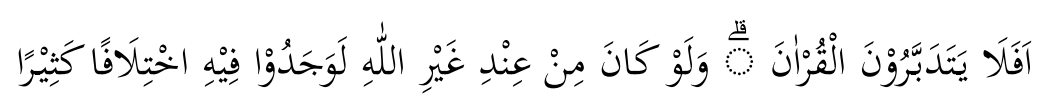

(artinya), “Tidakkah mereka mentadabburi Al-Qur'an, seandainya ia bukan dari sisi Allah mereka akan dapati padanya pertentangan yang banyak." 104

\footnotetext{
${ }^{101}$ Al-Qur'an, Al-Mujadalah/58: 7.

${ }^{102}$ Abdul Aziz Al-Tharifi, Al-Khurrasaniyyah Fi Syarh 'Aqidati Al-Raziyyain (Riyadh: Makbatah Dar AlMinhaj, 1437 H), h. 338.

${ }^{103}$ Al-Utsaimin, Al-Qawa'id Al-Mutsla, h. 74.

${ }^{104}$ Al-Qur'an, An-Nisa'/4: 82.
} 
Ibnul Qayyim mengatakan, “Allah mengabarkan bahwa Ia menciptakan langit dan bumi, lalu bersemayam di atas "Arsy-Nya dan kemudian bahwa Ia bersama dengan makhluk-Nya melihat perbuatan-perbuatan mereka dari atas 'ArsyNya." 105

Hakekat kebersamaan secara bahasa tidak bertentangan dengan sifat Al-'Uluw. Keduanya bisa terjadi pada makhluk, seperti dikatakan dalam bahasa arab, Ma zilna nasiru wal qamaru ma'ana, (artinya), kita dari tadi berjalan dan bulan selalu bersama kita.

Perkataan semacam ini bukanlah sebuah kontradiksi dan tidak difahami bulan turun ke bumi. Dan masih dikatakan bersama padahal jarak keduanya sangat jauh. Jika ini saja dapat terjadi pada makhluk, maka lebih mungkin lagi terjadi pada Allah.

Karena siapa yang mengetahui urusan kita, selalu melihat, mendengar apa yang kita ucapkan, melihat apa yang kita perbuat, mengatur segala urusan kita maka hakikatnya Dia bersama dengan kita meskipuan Ia berada di atas 'Arsy-Nya secara hakikat juga.

Kemudian, memaknai sebuah teks sesuai dengan konteksnya bukan memalingkan sebuah teks dari makna asalnya (ta'wil), namun ia adalah amanah ilmiah dalam memahami ungkapan bahasa arab yang berbeda-beda.

Seperti memahami Al-Ma'iyyah di atas bahwa bersamanya Allah dengan hamba-Nya bukan berarti Allah berada di sampingnya, tapi penglihatan Allah terhadap hamba-Nya. Hal ini sesuai dengan qarinah dan siyaq dalam bangunan ayat.

Kemudian contoh berikutya adalah firman Allah,

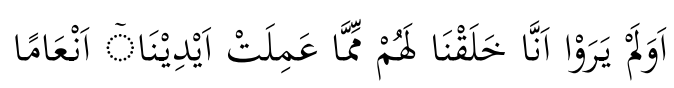

(artinya), "Tidakkah mereka melihat bahwa kami menciptakan untuk mereka binatang yang dilakukan oleh tangan Kami."

Ada dua kemungkinan dalam memahami ayat ini. ${ }^{107}$

Pertama, Allah menciptakan binatang dengan tangan-Nya sebagaimana Ia menciptakan Nabi Adam dengan tangan-Nya.

Kedua, Allah menciptakan binatang sebagaimana Ia menciptakan yang lainnya, tidak menciptakannya dengan tangan-Nya, namun disandarkan pada tangan tapi yang dimaksud adalah pemilik tangan tersebut.

\footnotetext{
${ }^{105}$ Al-Utsaimin, Al-Qawa'id Al-Mutsla, h. 77.

${ }^{106} \mathrm{Al}$-Qur'an, Yasin/36: 71.

${ }^{107}$ Al-Utsaimin, Al-Qawa'id Al-Mutsla, h. 94-95.
} 
Pemahaman yang pertama tentu bukan makna yang dimaksud karena dua hal;

1. Dari segi lafaznya tidak mendukung makna tersebut. Seperti dalam firman Allah,

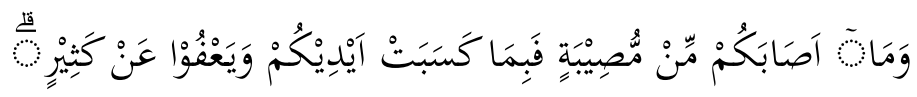

(artinya), "Dan apa yang menimpa kalian berupa musibah maka itu karena apa yang diperbuat oleh tangan kalian, dan Allah memaafkan banyak (dari kesalahankesalahanmu)."

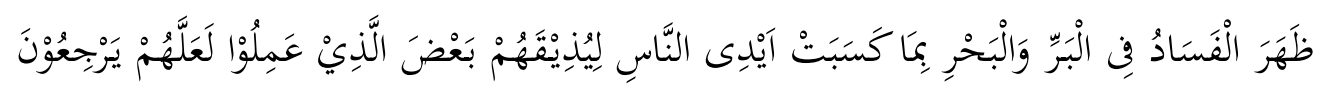

(artinya), "Telah tampak kerusakan di darat dan di laut disebabkan karena perbuatan tangan manusia; Allah menghendaki agar mereka merasakan sebagian dari (akibat) perbuatan mereka, agar mereka kembali (ke jalan yang benar)."109

Yang dimaksud dari dua ayat ini adalah perbuatan manusianya, meskipun ada perbuatan yang tidak dilakukan oleh tangannya. Berbeda jika lafaznya seperti dalam firman Allah,

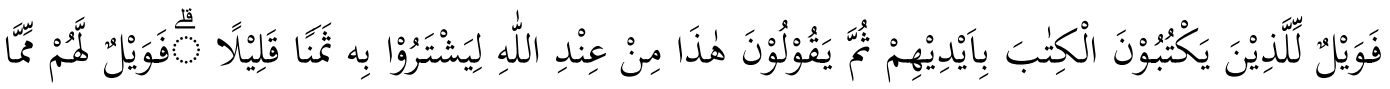

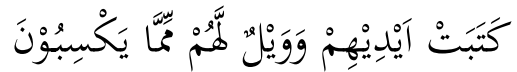

(artinya), "Maka celakalah orang-orang yang menulis kitab dengan tangan mereka (sendiri), kemudian berkata, "Ini dari Allah," (dengan maksud) untuk menjualnya dengan harga murah. Maka celakalah mereka, karena tulisan tangan mereka, dan celakalah mereka karena apa yang mereka perbuat."110

Ini menunjukkan perbuatan tangan secara langsung.

2. Jika maknanya adalah Allah menciptakan binatang tersebut dengan tangan-

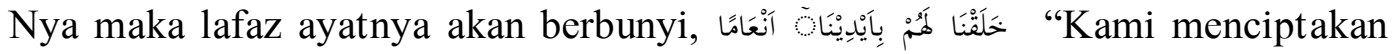
binatang dengan tangan Kami untuk mereka," sebagaimana yang Allah firmankan tentang penciptaan Nabi Adam,

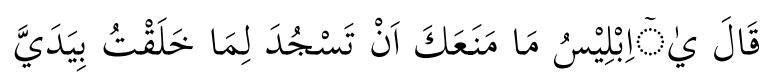

(artinya), "(Allah) berfirman, "Wahai Iblis, apakah yang menghalangi kamu sujud kepada yang telah Aku ciptakan dengan kedua tangan-Ku."111

\footnotetext{
${ }^{108}$ Al-Qur'an, Asy-Syura/42: 30

${ }^{109} \mathrm{Al}-\mathrm{Qur}$ 'an, Ar-Rum/30: 41.

${ }^{110} \mathrm{Al}-\mathrm{Qur}$ 'an, Al-Baqarah/2: 79.

${ }^{111}$ Al-Qur'an, Shad/38: 75 .
} 
Sebagai bentuk pemuliaan untuk Nabi Adam alaihis salam dan keturunannya karena diciptakan langsung dengan kedua tangan Allah.

Perbedaan makna dari beberapa ayat diatas karena perbedaan konteksnya dalam bangunan kalimat.

Yang disela dengan kata 'amilat dan kasabat عَمَلَتْ، كَسَبَتْ berarti perbuatan sang pemilik tangan, bukan perbuatan tangannya secara langsung.

Adapun jika menggunakan kata $b a^{\prime} \varphi$ dengan kata biyadayya, biaidihim, biaidina, maka ini yang dimaksud adalah perbuatan tangan secara langsung.

Melihat pentingnya hal ini, Al-Utsaimin mengatakan, "Maka perhatikan perbedaan ini (konteks/siyaq bahasa arab), mencermati perbedaan-perbedaan yang samar seperti ini merupakan jenis ilmu yang sangat baik, dengannya akan selesai ragam permasalahan."112

Inilah setidaknya empat poin sebagai kritik Teologi Salafiyah atas pemahaman Ahli Kalam terhadap sifat-sifat Allah. Sebenarnya masih ada beberapa poin yang bisa menjadi kritik. Diantaranya; 1. tidak menyerap semua dalil dalam satu pembahasan, 2. membedakan antara satu sifat dengan sifat Allah yang lainnya dan, 3. membedakan antara sifat dan dzat. Dua poin terakhir ini dijelaskan oleh Syaikhul Islam Ibnu Taimiyah dalam Risalah Tadmuriyah.

Empat poin di atas sudah cukup mewakili sebagai penyebab utama ragam interpretasi Ahli Kalam dalam menalar sifat-sifat Allah.

\section{KESIMPULAN}

Dari uraian di atas, dapat ditarik beberapa kesimpulan:

1. Semua Ahlul Qiblah sepakat bahwa Allah tidak serupa dengan apapun, Allah harus disucikan dari segala bentuk yang mengurangi kemuliaan dan keagungan-Nya. Namun upaya ini, dalam pandangan Teologi Salafiyah membuat Ahli Kalam terjatuh dalam banyak bentuk ilhad, berupa tahrif, ta'thil, takyif, tamtsil, ta'wil dan tafwidh dalam memahami sifat-sifat Allah.

2. Persentase terbesar kekeliruan Ahli Kalam terjadi pada itsbat. Sehingga mereka tidak menetapkan nama-nama dan sifat-sifat Allah sesuai yang diinginkan Allah dan Rasul-Nya.

3. Penyebab interpretasi keliru Ahli Kalam dalam memahami sifat-sifat Allah bersumber dari dasar berfikir yang sama, dan ini juga sebagai kritik Teologi Salafiyah terhadap mereka. yakni:

${ }^{112}$ Al-Utsaimin, Al-Qawa'id Al-Mutsla, h. 96. 
a. Adanya persepsi yang keliru bahwa jika menetapkan sifat-sifat Allah sesuai dengan maknanya akan terjatuh pada tasybih.

b. Adanya persepsi yang salah bahwa jika menetapkan sifat Allah sesuai dengan maknanya akan terjatuh kepada tasybih pada konsekuensi dari sifat tersebut. Sehingga atas persepsi tidak benar tersebut mereka menuduh Ahlus Sunnah sebagai Mujassimah dan Musyabbihah.

c. Terlalu berlebih dalam melakukan tanzih dan menyangka bahwa tafwidh adalah solusi sebagai bentuk ta'zhim kepada Allah.

d. Kemudian adanya kekeliruan dalam memahami ungkapan bahasa Arab sesuai konteksnya. Sehingga melakukan ta'wil terhadap sifat-sifat Allah.

\section{DAFTAR PUSTAKA}

'Atha' Shufi, Abdul Qadir. (1439 H). Muqaddimat fi Al-Firaq wa Al-Iftiraq. Madinah Al-Munawwarah, Dar Al-Imam Muslim.

'Atha' Shufi, Abdul Qadir. (2018 M). Al-'Asy'ariyah: Diktat Mata Kuliah Firaq di Universitas Islam Madinah. Madinah Munawwarah, Univ. Islam Madinah,

Abdul Akhir Al-Ghunaimi, (1415 H). Aqidat Al-Hafizh Ibn Katsir Baina AlTafwidh wa Al-Ta'wil. Dammam, Dar Al-Akhla'.

Abdul Aziz bin Baz. (1435 H). Ta'liqat Samahat Al-Sayikh Al-'Allamah Abdil Aziz bin Baz 'Ala Al-Risalah Al-Hamawiyah Al-Kubro. Riyadh, Muassasah Abdul Aziz bin Baz Al-Khairiyah.

Abdurrahman bin Ahmad Al-Iji. Al-Mawaqif fi 'Ilm Al-Kalam. Beirut, 'Alam AlKutub.

Abu Hamid Al-Ghazali. (1403 H). Al-Iqtishad fi Al-I'tiqad. Beirut, Dar AlKutub Al-'Ilmiyyah.

Abu Hamid Al-Ghazali. (1405 H). Qawa'id Al-'Aqa'id. Beirut, 'Alam Al-Kutub.

Abu Ya'la, Muhammad bin Husain Ibn Al-Farra'. (1407 H). Ibthal Al-Ta'wilat Li Akhbar Al-Shifat. Kuwait, Dar Ilaf Al-Dauliyah.

Ahmad bin Hambal. (1424 H). Ar-Radd 'Ala Al-Zanadiqah wa Al-Jahmiyah. Riyadh, Dar Al-Tsabat.

Ahmad Isa Al-Anshari. Syarah Umm Al-Barahin. Beirut, Al-Maktabah AlTsaqafiyah.

Al-Albani, Muhammad Nashiruddin. (1419 H). Shahih Sunan Al-Tirmidzi. Riyadh, Maktabah Al-Ma'arif.

Al-Baihaqi, Abu Bakar Ahmad bin Al-Husain bin Ali. Al-Asma' wa Al-Shifat.

Beirut, Dar Al-Kutub Al-'Ilmiiyyah.

Al-Bukhari, Muhammad bin Ismail. (1417 H). Shahih Al-Bukhari. Riyadh, Dar Al-Salam.

Al-Busti, Muhammad bin Hibban. (1432 H). Shahih Ibnu Hibban. Beirut, Dar Ibnu Hazm.

Al-Buthi, Muhammad Sa'id Ramadhan. (1982). Kubra Al-Yaqiniyyat AlKauniyyah. Damaskus, Dar Al-Fikr. 
Al-Dzahabi, Syamsuddin Muhammad bin Utsman. (1416 H). Al- 'Uluw Li Al'Aliy Al-Ghaffar fi Idhah Shahih Al-Akhbar min Saqimiha. Riyadh, Maktabah Adhwa' Al-Salaf.

Al-Ghunaiman, Abdullah bin Muhammad. (1428 H). Syarah Kitab At-Tauhid min Shahih Al-Bukhari. Riyadh, Dar Al-'Ashimah.

Al-Hamd, Muhammad bin Ibrahim. (1439 H).Rasail fil 'Aqidah. Riyadh, Dar Ibnul Jauzi.

Al-Hilali, Taqiyuddin Ibn Abd Al-Qadir. (1427 H). Sabil Al-Rasyad fi Hadyi Khair Al-'Ibad. Amman, Dar Al-Atsariyah.

Ali Amir, Jabir Idris. (1419 H). Manhaj Al-Salaf wa Al-Mutakallmin fi Muwafaqati Al-'Aql li Al-Naql wa Atsaru Al-Manhajaini fi Al-'Aqidah. Riyadh, Maktabah Adhwa' As-Salaf.

Al-Naisaburi, Muslim bin Hajjaj. (1421 H). Shahih Muslim. Riyadh, Dar AlSalam.

Al-Nashir Al-Rasyid, Abdul Aziz. (1416 H).At-Tanbihat Al-Saniyyah 'Ala Al'Aqidah Al-Wasithiyyah. Riyadh, Dar Al-Rasyid.

Al-Qadhi Abdul Jabbar. (1416 H). Syarh Ushul Al-Khamsah. Cairo, Maktabah Wahbah.

Al-Sajistani, Sulaiman bin Asy'ats. (1417 H). Sunan Abi Dawud. Riyadh, Maktabah Al-Ma'arif.

Al-Sayyid Ali Al-Samarra'i, Thaha Khalid. ( t.th). Masa'il Al-Khilaf Baina Al'Asy'ariyyah wa Al-Maturidiyyah. Beirut, Dar Al-Kutub Al-'Ilmiyyah.

Al-Tharifi, Abdul Aziz bin Marzuq. (1437 H). Al-Khurrasaniyyah Fi Syarh 'Aqidati Al-Raziyyain. Riyadh, Makbatah Dar Al-Minhaj.

Al-Tharifi, Abdul Aziz bin Marzuq. (1438 H). Al-Maghribiyah Fi Syarh Al'Aqidah Al-Qairawaniyyah. Riyadh, Maktabah Dar Al-Minhaj.

Al-Utsaimin, Muhammad bin Shalih. (1435 H).Al-Qawa'id Al-Mutsla fi Shifatillahi Ta'ala wa Asmaihi Al-Husna. Riyadh, Madar Al-Wathan.

Hasibuan, Hadi Rafitra. (2017). Aliran Asy'ariyah, Kajian Historis dan Pengaruh Aliran Kalam Asy'ariyah. Jurnal Al-Hadi, 2(2), 433-441.

Ibnu Abd Al-Barr. Jami' Bayan Al- 'Ilm Wa Fadhlihi. Beirut, Dar Al-Kutub AlIlmiyah.

Ibnu Jama'ah. (1410 H). Idhah Al-Dalil fi Qat'i Hujaji Ahl Al-Ta'thil. Cairo, Dar Al-Salam.

Ibnu Quddamah Al-Maqdisi. (1409 H). Itsbat Shifat Al- 'Uluw. Damaskus, Mu'assasah 'Ulum Al-Qur'an.

Ibnu Taimiyah, Taqiyuddin Ahmad bin Abdul Hamid. (1402 H). Syarh Hadits Al-Nuzul. Beirut, Al-Maktab Al-Islami.

Ibnu Taimiyah, Taqiyuddin Ahmad bin Abdul Hamid. (1406 H). Minhaj AsSunnah An-Nabawiyah. Riyadh, Univ. Islam Imam Muhammad bin Suud.

Ilhamuddin., \& Ilhamy Nasution, Muhammad Lathief. (2017). Teologi Islam, Warisan Pemikir Muslim Klasik. Medan, Perdana Publishing.

Imam, Karim. (n.d.). Al- 'Asya'irah Su'al wa Jawab. Al-Manshurah - Mesir, Dar Al-Lu'lu'ah. 
Iskandar, A., Aqbar, K. (2019). Reposisi Praktik Ekonomi Islam: Studi Kritis Praktik Ekonomi Islam di Indonesia. Nukhbatul 'Ulum: Jurnal Bidang Kajian Islam, 5(1), 39-53.

Kementerian Agama. (2012). Al-Qur'an dan Terjemahannya. Depok, Sabiq. Khalifah, Abdurrahman. (1420 H). Al-Musyabbihah wa Al-Mujassimah. Cairo, Al-Maktabah Al-Takhassusiyah li Al-Radd Ala Al-Wahhabiyah.

Kholilurrohman. (2018). Meluruskan Distorsi Dalam Ilmu Kalam. Tangerang, Nurul Hikmah Press.

Muhammad Ba'abdullah, Muhammad Bakarim. (1437 H). Wasathiyatu Ahlis Sunnah Baina Al-Firaq. Madinah, Maktabah Al-'Ulum wa Al-Hikam.

Ulum, Bahrul. (2016). Dinamika Ilmu Kalam Sunni. Jurnal Pemikiran dan Pendidikan Islam El-Banat, 6(2), 143-154. 